Jurnal Keuangan dan Perbankan, Vol.20, No.1 Januari 2016, hlm. 104-115

Terakreditasi SK. No. 040/P/2014

http://jurkubank.wordpress.com

\title{
KAITAN KONDISI MAKROEKONOM I DENGAN NON PERFORMING FINANCING BERDASARKAN SEKTOR EKONOMI PADA PERBANKAN SYARIAH DI INDONESIA
}

\author{
Nunung Nuryartono \\ Imam Teguh Saptono \\ Guruh Herman Was'an \\ M anajemen Syariah, Program Pascasarjana M anajemen dan Bisnis Institut Pertanian Bogor
}

\begin{abstract}
This study attempts to identify the effect of macroeconomic variables to $\mathrm{N}$ on Performing Financing (N PF) based on economic sector of Islamic banking in Indonesia. Themacroeconomic variables used in this study are Sertifikat Bank Syariah Indonesia (SBIS), Industrial Production Index (IPI), inflation, and exchangerate.The data usedin this stu dyis amonthly timeseries dataan dsecondaryin the periodj an uary 2009toD ecember 2014. The analytical methodused isV ector E rror Correction M odel (VECM ). Based on theresult of simulating V ariance D ecomposition (VD) and Impulse Response Function (IRF), it is found that, exchange rate tends to be the innovation of thesmallest in the short-term and long-term. The conclusion that in theshort term or long term, changes in macroeconomic variables affects theN PF of thefour sectors with theamount of variability of thirty to fifty percent, which N PF agriculture, forestry and agricultural in puts, mining, industry, and transport, storageand communication.
\end{abstract}

Keyw ords: N on Performing Financing, economic sector, macroeconomic

Perbankan memiliki peranan penting dalam pertumbuhan ekonomi di Indonesia. Jumlah penduduk Indonesiayang mencapai 250jutajiwa dan sebagai jumlah penduduk muslim terbesar di dunia menghendaki sistem perbankan yang sesuai dengan nilai-nilai Islamyaitu perbankan syariah. Mulai beroperasinya Bank Muamalat tahun 1992 diiringi dengan dikeluarkannya UU No. 7 tahun 1992 tentang perbankan yang mengeluarkan system perbankan bagi hasil dan dimulailah era system perbankan ganda (dual banking system).

Selama kurun waktu 2005 sampai dengan 2014 perkembangan perbankan syariah di Indonesia telah menunjukan pencapaian yang bagus dengan tingkat pertumbuhan yang konsisten. Dari sisi aset selalu mengalami peningkatan dengan rata-rata kenaikkan sebesar 33 persen setiap tahunnya dengan posisi tahun 2014 aset perbankan syariah mencapai Rp

Korespondensi dengan Penulis:

Nunung Nuryartono: Telp. -

Email: - 


\section{Kaitan Kondisi Makroekonomi dengan Non Performing Financing Berdasarkan Sektor Ekonomi ...}

N unung N uryartono, Imam Teguh Saptono, \& G uruh H erman Was'an

272,34 triliun. Begitu pula dengan pertumbuhan DanaPihak Ketiga dan penyaluran pembiayaan dengan rata-rata kenaikkan sebesar 34 persen setiap tahunnya. Sedangkan rasio N on Performing Financing (NPF) pula mengalami penurunan dari tahun 2006 sampai tahun 2012 dengan rata-rata penurunan sebesar 0,42 persen, namun mengalami peningkatan pada tahun 2013 dan 2014 sebesar 0,4 persen dan 1,71 persen.

Risiko pembiayaan yang tercermin pada N PF menurut PBI No. 13/ 23/ PBI/ 2011 adalah risiko aki bat kegagalan nasabah atau pihak lain dalam memenuhi kewajiban kepada bank sesuai dengan perjanjian yang disepakati.Secara umum rasio NPF yang terdapat pada perbankan syariah masih digolongkan baik karena masih dibawah lima persen sesuai dengan kriteria Bank Indonesia namun sejak tahun 2012 NPF pada perbankan Syariah cenderung meningkat dengan NPF tertinggi pada bulan Februari 2015 sebesar 5,10 persen. Bila melihat rasio NPF berdasarkan sektor ekonomi pada tahun 2009 hingga 2014 dimana sektor ekonomi yang berada dibawah rasio NPF rata-rata perbankan syariah pada periode tersebut atau dibawah 3,68 persen hanya tiga dari sembilan sektor ekonomi yaitu sektor listrik, gas, dan air, sektor jasa dunia usaha, dan sektor jasa sosial/ masyarakat. $\mathrm{Hal}$ ini menunjukkan bahwa terdapat perbedaan kemampuan maintenance perbankan syariah kepada nasabah berdasarkan sektor usaha nasabah atau adanya perubahan yang disebabkan faktor internal dan eksternal yang memiliki dampak berbeda kepada nasabah perbankan syariah.

Indonesiamemiliki sistem perekonomian terbuka yang menyebabkan pelaksanaan kebijakan moneter. Menurut Taylor (1995) transmisi kebijakan moneter adalah proses dimana kebijakan moneter yang ditransmisikan untuk menjaga pertumbuhan ekonomi dan tingkatinflasi.Untuk mencapai tujuan itu Bank Indonesia menetapkan suku bunga sebagai instrumen kebijakan utama dengan melalui beberapa jalur untuk mempengaruhi aktivitas kegiatan perekonomian. Sal ah satu jalur transmisi ter- sebut berimplikasi pada nilai tukar (exchange rate).Oleh karena itu kebijakan menaikkan atau menurunkan Bl rate berimplikasi tidak saja pada inflasi, tetapi juga pada pertumbuhan ekonomi, dan nilai tukar.Perubahan kondisi perekonomian tersebut merupakan salah satu faktor eksternal yang mempengaruhi pelaku usaha perbankan syariah (N ursechavia \& A bduh, 2014).Imbal hasil Sertifikat Bank Indonesia Syariah juga memberikan pengaruh terhadap N PF perbankan syariah (Poetry \& Sanrego, 2012).Namun demikian respon yang ditunjukkan oleh NPF masing-masing sektor ekonomi pada perbankan syariah dalam menghadapi perubahan pada lingkup makroekonomi diperkirakan berbeda.Oleh karena itu perlu dibuktikan secara empiris mengenai dampak dari adanya perubahan kondisi makroekonomi yaitu inflasi, nilai tukar, pertumbuhan ekonomi, dan imbal hasil SBIS terhadap NPF berdasarkan sektor ekonomi pada perbankan syariah di Indonesia.Respon yang ditimbulkan masing-masing NPF sektor ekonomi memungkinkan tidak merepresentasikan seluruh karakteristik sektor ekonomi tersebut karena market shareperbankan syariah di Indonesiayang hanya sebesar lima persen.

\section{METODE}

Penelitian ini menggunakan data sekunder pada Bank Umum Syariah dan UnitUsaha Syariah yang mewakili perbankan syariah di Indonesiayang meliputi data kuantitatif bulanan pada rentang waktu antara bulan Januari 2009 sampai Desember 2014. Data rasio NPF masing-masing sektor ekonomi, imbal hasil SBIS, dan nilai tukar diperoleh dari Statistik Ekonomi dan Keuangan Bank Indonesia (SEKI-BI) dan Statistik Perbankan Syariah (SPS) Bank Indonesia, sedangkan data inflasi dan pertumbuhan output diperoleh dari Badan Pusat Statistik (BPS).Seluruh data yang digunakan pada penelitian ini merupakan data riil yang ditransformasikan ke dalam bentuk logaritma natural (LN) kecuali variabel yang sudah dalam satuan persen atau rasio yaitu NPF, imbal hasil SBIS, IPI, dan IHK. 
Penelitian ini menggunakan metodeanalisis V ector A utoregressive (VAR) yang bertujuan untuk menjawab permasalahan seperti yang telah dirumuskan sebelumnya.V ector Error Correction M odel (VECM ) digunakan jika data yang digunakan tidak stationer pada tingkat level sehingga harus didiferensiasikan pada turunan pertama (first differencing) dan memiliki hubungan jangka panjang atau terkointegrasi (Enders, 2004). Pada analisis VAR dan VECM ada beberapa tahap yang perlu dilakukan yaitu uji stationeritas data, uji stabilitas, penentuan lag optimal, uji kointegrasi, penentuan model umum VECM, dan Innovation A ccounting yang terdiri dari analisis Impulse R esponse Function (IRF) dan V ariance D ecomposition (VD).

Secara umum model VECM sebagai berikut:

$$
\begin{aligned}
& \Delta x_{t}=\pi_{0}+\pi x_{t-1}+\pi_{1} \Delta x_{t-1}+ \\
& \pi_{2} \Delta x_{t-2}+\ldots+\pi_{p} \Delta x_{t-p}+\varepsilon_{t}
\end{aligned}
$$

Keterangan:

: vector yang berisi variabel yang dianal isis dalam penelitian

: vector intesep berukuran (n.1)

$\Pi \quad$ : matriks dengan elemen , dimana dengan elemen ' $\neq 0$

: matriks koefisien berukuran (n.n) dengan elemen (i)

: vectorerror berukuran (n.1) dengan elemen

\section{HASIL DAN PEMBAHASAN \\ Kestasioneran Data}

Estimasi VAR perlu dilakukan uji stasioner terlebih dahulu dimana data dapat dikatakan stasioner jika nilai rata-rata dan variannya untuk berbagai lag yang berbeda nilainya adal ah konstan sepanjang waktu (Gujarati, 2003).Dalam penelitian ini untuk mendeteksi stasioner data dilakukan dengan menggunakan A ugmented Dickey-Fuller (ADF) test.

Tabel 1.Variabel penelitian

\begin{tabular}{clc}
\hline Variabel & \multicolumn{1}{c}{ Keterangan } & Satuan \\
\hline $\mathrm{NPF}_{1}$ & Rasio NPF dari sektor pertanian, kehutanan dan sarana pertanian & Persen \\
$\mathrm{NPF}_{2}$ & Rasio NPF dari sektor pertambangan & Persen \\
$\mathrm{NPF}_{3}$ & Rasio NPF dari sektor perindustrian & Persen \\
$\mathrm{NPF}_{4}$ & Rasio NPF dari sektor konstruksi & Persen \\
$\mathrm{NPF}_{5}$ & Rasio NPF dari sektor perdagangan, restoran, dan hotel & Persen \\
$\mathrm{NPF}_{6}$ & Rasio NPF dari sektor pengangkutan, pergudangan, dan komunikasi & Persen \\
$\mathrm{NPF}_{7}$ & Rasio NPF dari sektor listrik, gas, dan air & Persen \\
$\mathrm{NPF}_{8}$ & Rasio NPF dari sektor jasa dunia usaha & Persen \\
$\mathrm{NPF}_{9}$ & Rasio NPF dari sektor jasa sosial/ masyarakat & Persen \\
$\mathrm{SBIS}$ & Acuan imbal hasil yang ditetapkan Bank Indonesia & Persen \\
$\mathrm{IHK}$ & Proxy untuk mengukur tingkat inflasi (2007=100) & - \\
$\mathrm{ER}$ & Kurs nilai tengah Rupiah terhadap Dollar Amerika Serikat & Rp/ US\$ \\
$\mathrm{IPI}$ & Proxy untuk menghitung tingkat output dengan harga tahun dasar $2010=100$ & - \\
\hline
\end{tabular}




\section{Kaitan Kondisi Makroekonomi dengan Non Performing Financing Berdasarkan Sektor Ekonomi ...}

N unung N uryartono, Imam Teguh Saptono, \& G uruh H erman Was'an

Berdasarkan hasil uji akar unit (Tabel 2) pada tingkat first difference masih terdapat data yang tidak stasioner yaitu NPF sektor listrik, gas, dan air (NPF7). Oleh karena itu variabel NPF sektor listrik, gas, dan air (NPF7) tidak bisa digunakan dalam penelitian ini karena akan menghasilkan spurious regression dimana regresi dengan hasil yang bagus namun data yang digunakan tidak stasioner sehingga koefisien dari hasil estimasi menjadi tidak valid.

Penggunaan data first differenceakan menye babkan hilangnya informasi jangka panjang. Oleh karena itu untuk menganalisis informasi jangka panjang akan digunakan data level sehingga model VAR akan dikombinasikan dengan VECM.

Tabel 2.Uji Akar Unit

\begin{tabular}{lcccc}
\hline \multirow{2}{*}{ Variabel } & \multicolumn{2}{c}{ Level } & \multicolumn{2}{c}{ 1st D ifference } \\
\cline { 2 - 5 } & t stat & prob & t stat & prob \\
\hline SBIS & -2.2757 & 0.183 & -3.5351 & $0.010^{*}$ \\
IHK & -3.2455 & 0.084 & -5.9327 & $0.000^{*}$ \\
ER & -0.2131 & 0.931 & -7.1497 & $0.000^{*}$ \\
IPI & -6.1933 & $0.000^{*}$ & & \\
NPF1 & -4.7315 & $0.001^{*}$ & & \\
NPF2 & -3.4884 & $0.001^{*}$ & & \\
NPF3 & -2.2751 & 0.442 & -8.7103 & $0.000^{*}$ \\
NPF4 & -4.1260 & $0.002^{*}$ & & \\
NPF5 & -3.1864 & $0.025^{*}$ & & \\
NPF6 & -3.2201 & $0.023^{*}$ & & 0.999 \\
NPF7 & 0.254441 & 0.998 & 1.329638 & $0.000^{*}$ \\
NPF8 & -1.9264 & 0.319 & -5.6357 & $0.000^{*}$ \\
NPF9 & -2.4430 & 0.134 & -8.0775 & \\
\hline
\end{tabular}

*) signifikan pada ( $\alpha=5 \%$ )

Tabel 3.Hasil Uji Lag Optimum (nilai SC)

\begin{tabular}{llllrrrr}
\hline \multirow{2}{*}{ Variabel } & \multicolumn{7}{c}{ Lag } \\
\cline { 2 - 8 } & $\mathbf{0}$ & $\mathbf{1}$ & $\mathbf{2}$ & $\mathbf{3}$ & $\mathbf{4}$ & $\mathbf{5}$ & $\mathbf{6}$ \\
\hline NPF1 & 15.7 & $6.4^{*}$ & 7.2 & 8.3 & 9.4 & 5.6 & 10.8 \\
NPF2 & 18.4 & $8.9^{*}$ & 9.4 & 10.5 & 11.3 & 11.9 & 13.0 \\
NPF3 & 15.9 & $6.4^{*}$ & 7.2 & 8.1 & 9.1 & 9.7 & 10.8 \\
NPF4 & 15.9 & $6.8^{*}$ & 7.6 & 8.5 & 9.5 & 10.0 & 10.9 \\
NPF5 & 16.1 & $6.8^{*}$ & 7.6 & 8.6 & 9.7 & 10.2 & 11.2 \\
NPF6 & 17.2 & $7.7^{*}$ & 8.2 & 9.2 & 10.1 & 11.0 & 12.1 \\
NPF8 & 14.3 & $5.3^{*}$ & 5.9 & 7.0 & 7.9 & 8.5 & 9.6 \\
NPF9 & 16.3 & $6.5^{*}$ & 7.2 & 8.2 & 9.0 & 9.7 & 10.7 \\
\hline *) indicates lag order selected by the criterion & & & & & &
\end{tabular}




\section{Jurnal Keuangan dan Perbankan | PERBANKAN}

Vol. 20, N o.1, Januari 2016: 104-115

\section{Pengujian Lag Optimum}

Pengujian ini dapatmemanfaatkan beberapa pendekatan antara lain Likelihood Ratio (LR), Final Prediction Error (FPE), A kaike Information Criterion (AIC), Schwarz Information Criterion (SC), dan H annan-Q uinn Criterion (HQ). Jumlah lag optimum dalam penelitian ini menggunakan pendekatan pada nilai Schwarz Information Criterion (SC) yang terkecil atau minimum.

Penetapan lag optimum model yang digunakan dapat dilihat sesuai dengan Tabel 3 dimana lag yang terpilih adalah lag 1.Oleh karena itu, persamaan VAR dari model yang akan dibangun dalam penelitian ini berdasarkan lag optimum yang didapat adalah sebagai berikut:

$$
\Delta x_{t}=\pi_{0}+\pi x_{t-1}+\pi_{1} \Delta x_{t-1}(2)
$$

Keterangan:

: Vector yang berisi variabel yang dianalisis dalam penelitian

: Vector intesep berukuran (n.1)

$\Pi \quad$ : Matriks dengan elemen, dimana dengan elemen ' $\neq 00\left(\mathrm{NPF}_{1} / \mathrm{NPF}_{2} / \mathrm{NPF}_{3} / \mathrm{NPF}_{4} /\right.$ $\mathrm{NPF}_{5} / \mathrm{NPF}_{6} / \mathrm{NPF}_{8} / \mathrm{NPF}_{9} \mathrm{sbis}, \mathrm{er}$, cpi, dan ipi)

: Matriks koefisien berukuran (n.n) dengan elemen (i) $\left(\mathrm{NPF}_{1} / \mathrm{NPF}_{2} / \mathrm{NPF}_{3} / \mathrm{NPF}_{4} /\right.$ $\mathrm{NPF}_{5} / \mathrm{NPF}_{6} / \mathrm{NPF}_{8} / \mathrm{NPF}_{9}, \mathrm{sbis}, \mathrm{er}, \mathrm{cpi}$, dan ipi)

: Vector error berukuran (n.1) dengan elemen

\section{Pengujian Stabilitas VAR}

Pengujian stabil atau tidaknya estimasi model VAR yang telah dibentuk melalui VAR stability condition check yang berupa roots of characteristic polynomial terhadap seluruh variabel yang digunakan dikalikan jumlah lag dari masing-masing VAR. Jika modulus dari seluruh roots of characteristic polynomial $<1$ maka sistem persamaan VAR dapat dikategorikan stabil.

Tabel 4. Hasil Uji Stabilitas VAR

\begin{tabular}{llll}
\hline Variabel & \multicolumn{3}{c}{ M odulus } \\
\hline NPF1 & 0.031452 & s.d & 0.592697 \\
NPF2 & 0.169451 & s.d & 0.556080 \\
NPF3 & 0.046464 & s.d & 0.568536 \\
NPF4 & 0.004657 & s.d & 0.584591 \\
NPF5 & 0.085167 & s.d & 0.580413 \\
NPF6 & 0.150834 & s.d & 0.700557 \\
NPF8 & 0.022609 & s.d & 0.573836 \\
NPF9 & 0.060921 & s.d & 0.574920 \\
\hline
\end{tabular}

Berdasarkan hasil uji stabilitas VAR diketahui bahwa sistem VAR yang digunakan bersifat stabil dengan nilai modulus pada masing-masing model dari seluruh roots of characteristic polynomial kisaran 0.004-0.70. Setelah sistem persamaan VAR stabil maka dapat dilakukan estimasi terhadap VECM.

\section{Uji Kointegrasi}

Dalam penelitian ini data yang diperoleh tidak seluruhnya stasioner pada level sehingga estimasi dilakukan dengan menggunakan model VECM dan perlu dilakukan pengujian kointegrasi terlebih dahulu. Kointegrasi digunakan untuk memperoleh persamaan jangka panjang yang stabil. Jika terdapat lebih dari nol rank kointegrasi, maka metode VECM dapat digunakan dalam analisis. Kriteria untuk menguji ada atau tidaknya kointegrasi antar variabel menggunakan Johansen Cointegration Test berdasarkan tracestatistic. A pabila nilai trace statistic lebih besar daripada nilai kritis pada taraf nyata (5 persen) maka hal ini mengindikasikan adanya kointegrasi antar variabel. 
Kaitan Kondisi Makroekonomi dengan Non Performing Financing Berdasarkan Sektor Ekonomi ... N unung N uryartono, Imam Teguh Saptono, \& G uruh H erman Was'an

Tabel 5. Hasil Uji Kointegrasi

\begin{tabular}{|c|c|c|c|c|c|c|c|}
\hline \multirow[t]{3}{*}{ Variabel } & \multicolumn{7}{|c|}{ Trace Statistic } \\
\hline & \multicolumn{2}{|l|}{$\mathrm{HO}$} & $R=0$ & $\mathrm{R}=1$ & $R=2$ & $R=3$ & $R=4$ \\
\hline & \multicolumn{2}{|l|}{$\mathrm{H} 1$} & $\mathrm{R}>=1$ & $\mathrm{R}>=2$ & $R>=3$ & $R>=4$ & $\mathrm{R}>\Rightarrow$ \\
\hline \multirow{2}{*}{ NPF1 } & & Trace Stat & 117.38* & 63.39 & 33.98 & 10.38 & 3.14 \\
\hline & & $\alpha=0.05$ & $88.80^{*}$ & 63.88 & 42.92 & 25.87 & 12.52 \\
\hline \multirow{2}{*}{ NPF2 } & & Trace Stat & 117.66* & 61.52 & 27.91 & 11.33 & 4.10 \\
\hline & & $a=0.05$ & $88.80^{*}$ & 63.88 & 42.92 & 25.87 & 12.52 \\
\hline \multirow{2}{*}{ NPF3 } & & Trace Stat & 126.46* & 73.57* & 37.68 & 10.43 & 3.50 \\
\hline & & $a=0.05$ & $88.80^{*}$ & 63.88* & 42.92 & 25.87 & 12.52 \\
\hline \multirow{2}{*}{ NPF4 } & & Trace Stat & $115.71 *$ & 62.94 & 32.23 & 10.13 & 3.04 \\
\hline & & $\alpha=0.05$ & 88.80* & 63.88 & 42.92 & 25.87 & 12.52 \\
\hline \multirow{2}{*}{ NPF5 } & & Trace Stat & $110.44^{*}$ & 56.73 & 24.00 & 9.64 & 2.97 \\
\hline & & $a=0.05$ & $88.80^{*}$ & 63.88 & 42.92 & 25.87 & 12.52 \\
\hline \multirow{2}{*}{ NPF6 } & & Trace Stat & 122.88* & $64.86 *$ & 27.98 & 9.80 & 3.20 \\
\hline & & $a=0.05$ & $88.80^{*}$ & 63.88* & 42.92 & 25.87 & 12.52 \\
\hline \multirow{2}{*}{ NPF8 } & & Trace Stat & 121.88* & 68.79* & 33.80 & 10.39 & 3.37 \\
\hline & & $a=0.05$ & 88.80* & 63.88* & 42.92 & 25.87 & 12.52 \\
\hline \multirow{2}{*}{ NPF9 } & & Trace Stat & 118.55* & 65.68* & 31.16 & 10.16 & 2.94 \\
\hline & & $a=0.05$ & $88.80^{*}$ & 63.88* & 42.92 & 25.87 & 12.52 \\
\hline
\end{tabular}

*) adanya kointegrasi pada ( $\alpha=5 \%)$

\section{Uji Kausalitas Granger}

Dalamuji kausalitas Granger ini dapat dilihat adanya pengaruh masa Ialu terhadap kondisi sekarang.

Tabel 6. Hasil Uji Kausalitas Granger

\begin{tabular}{|c|c|c|c|c|}
\hline Variabel & SBIS & IHK & ER & IPI \\
\hline NPF1 & $\neq$ & $\rightarrow$ & $\rightarrow$ & $\rightarrow$ \\
\hline NPF2 & $\leftrightarrow$ & $\neq$ & $\neq$ & $\neq$ \\
\hline NPF3 & $\rightarrow$ & $\neq$ & $\rightarrow$ & $\neq$ \\
\hline NPF4 & $\rightarrow$ & $\neq$ & $\neq$ & $\neq$ \\
\hline NPF5 & $\neq$ & $\neq$ & $\neq$ & $\neq$ \\
\hline NPF6 & $\rightarrow$ & $\neq$ & $\rightarrow$ & $\neq$ \\
\hline NPF8 & $\rightarrow$ & $\neq$ & $\rightarrow$ & $\neq$ \\
\hline NPF9 & $\rightarrow$ & $\neq$ & $\rightarrow$ & $\neq$ \\
\hline
\end{tabular}

Dalam uji kausalitas granger, untuk melihat ada atau tidaknya hubungan kausalitas di antara variabel-variabel yang ada di dalam model dapat dilihat dari nilai probabilitasnnya. Melihat ada tidaknya hubungan kausalitas digunakan nilai pro- babilitas yang dibandingkan dengan nilai kritis yang digunakan. A pabila nilai probabilitasnya kurang dari taraf nyata yang ditentukan dimana dalam penelitian ini yaitu lima persen maka data tersebut sudah memiliki hubungan kausalitas.

\section{Analisis Impulse Response Function (IRF)}

Analisis impulse response dilakukan untuk menjelaskan jejak respon dalam jangka pendek maupun jangka panjang pada satu variabel terhadap guncangan (shock) variabel Iain. Analisis IRF pada penelitian ini dilakukan untuk menilai respon variabel NPF berdasarkan sektor ekonomi pada perbankan syariah terhadap kondisi makroekonomi.

\section{Pengaruh Guncangan Imbal Hasil SBIS terhadap NPF}

Berdasarkan Gambar 1, respon positif terhadap guncangan imbal hasil SBIS ditunjukkan oleh NPF sektor pertanian, kehutanan dan sarana 


\section{Jurnal Keuangan dan Perbankan | PERBANKAN}

Vol. 20, N o.1, Januari 2016: 104-115

pertanian (NPF1), pertambangan (NPF2), perindustrian (NPF3), perdagangan, restoran dan hotel (NPF5), dan jasa dunia usaha (NPF8). NPF sektor pertambangan (NPF2) merespon positif lebih besar dibandingkan sektor lainnya.Hal tersebut dapat didasari dari hasil pengujian kausal itas yang menunjukkan bahwa perubahan imbal hasil SBIS mempengaruhi secara langsung NPF sektor pertambangan. Selain itu pendapatan sektor pertambangan sangat sensitif dengan harga komoditas tambang itu sendiri. Salah satu harga komoditas sektor pertambangan yang saat ini sedang menurun yaitu batu bara dimana Harga Batubara A cuan (HBA) pada Desember 2013 dan Desember 2014 sebesar USD 80,31 dan USD 64,65 per ton atau mengalami penurunan sebesar 19,50 persen. Guncangan imbal hasil SBISyang dalam hal ini kenaikkan imbal hasil SBIS menyebabkan semakin besarnya pengembalian angsuran atas pembiayaan dan ditambah dengan penurunan hargakomoditas sektor pertambangan akan menurunkan repayment capacity kepada bank syariah yang tercermin pada peningkatan rasio NPF pada sektor ini.

Sedangkan respon negatif terhadap guncangan imbal hasil SBIS ditunjukkan oleh NPF sektor konstruksi (NPF4), dan pengangkutan, pergudangan dan komunikasi (NPF6), dan jasa sosial/ masyarakat (NPF9).NPF sektor pengangkutan, pergudangan dan komunikasi (NPF6) merespon negatif lebih besar dibandingkan sektor lainnya. $\mathrm{Hal}$ tersebut dapat didasari dari hasil pengujian kausalitas terlihat bahwa kenaikkan imbal hasil SBIS tidak mempengaruhi secara langsung N PF sektor pengangkutan, pergudangan dan komunikasi dan dapat dijelaskan dengan transmisi kebijakan moneter melalui jalur nilai tukar.Kenaikkan imbal hasil SBIS sebagai proxy suku bunga pada perbankan syariah akan mendorong investor asing untuk menanamkan modal ke dalam instrumentinstrumen keuangan di Indonesia seperti SBIS karena akan mendapatkan tingkat pengembalian yang lebih tinggi. Aliran modal masuk asing ini pada gilirannya akan mendorong apresiasi nilai tukar rupiah dan mengakibatkan harga barang impor lebih murah. Menurut Yudanto dan Santoso (1998) apresiasi rupiah akan memberikan pengaruh penurunan cost sektor pengangkutan, pergudangan dan komunikasi seperti pengadaan sparepart kendaraan maupun pembelian alat transportasi. $\mathrm{Hal}$ ini akan menyebabkan semakin tingginya pendapatan pada sektor pengangkutan, pergudangan dan komunikasi yang tercermin pada penurunan rasio NPF sektor ini. Hubungan negatif yang ditunjukkan antara guncangan imbal hasil SBIS terhadap NPF sektor ekonomi ini sesuai dengan hasil penelitian Poetry \&Sanrego (2012).

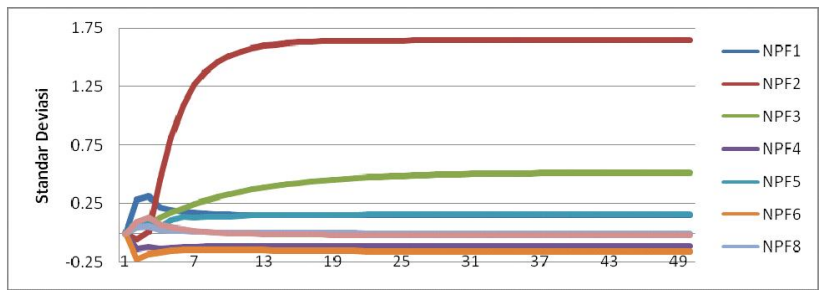

Gambar 1. Respon NPF Perbankan Syariah Berdasarkan Sektor Ekonomi terhadap Shock Imbal Hasil Acuan (Imbal Hasil SBIS)

\section{Pengaruh Guncangan Inflasi terhadap NPF}

Berdasarkan Gambar 2, dapat dilihat bahwa guncangan inflasi direspon negatif oleh hampir seluruh NPF sektor ekonomi kecuali NPF sektor konstruksi (NPF4) dan sektor pengangkutan, pergudangan dan komunikasi (NPF6). Tekanan inflasi dari sisi biaya merupakan sumber signifikan dari inflasi dalam pembentukan harga di Indonesia. Perusahaan memanfaatkan kondisi ini dengan menaikkan harga barang dan jasa.Ini memungkinkan meningkatnya pendapatan perusahaan, yang akibatnya dapat mengakibatkan meningkatkan repayment capacity perusahaan kepada bank syariah.

NPF sektor pertanian, kehutanan dan sarana pertanian (NPF1) merespon negatif lebih besar terhadap inflasi dibandingkan sektor lainnya, hal ini dapat diakibatkan karena tingginya inflasi dan 


\section{Kaitan Kondisi Makroekonomi dengan Non Performing Financing Berdasarkan Sektor Ekonomi ...}

umumnya permintaan pada sektor ini bersifatine Iastis. Berdasarkan data Badan Pusat Statistik, inflasi pada sektor pertanian, kehutanan dan sarana pertanian tahun 2013 dan 2014 merupakan kedua terbesar yaitu sebesar 11,35 dan 10,57 persen dibawah sektor traspor, komunikasi, dan jasa keuangan. Permintaan pada sektor pertanian, kehutanan dan sarana pertanian pada umumnya bersifat inelastis sehingga kenaikkan harga tidak terlalu mempengaruhi permintaan pada sektor ini. Oleh karena itu, guncangan inflasi dapat menyebabkan kenaikkan pendapatan sehingga mengakibatkan meningkatkan repayment capacity pada sektor pertanian, kehutanan dan sarana pertanian kepada bank syariah yang tercermin pada penurunan rasio NPF sektor ini. Hubungan negatif yang ditunjukkan antara guncangan inflasi terhadap hampir seluruh N PF sektor ekonomi ini sesuai dengan hasil penelitian Nursechavia \& A bduh (2014) dan Poetry \&Sanrego (2012).

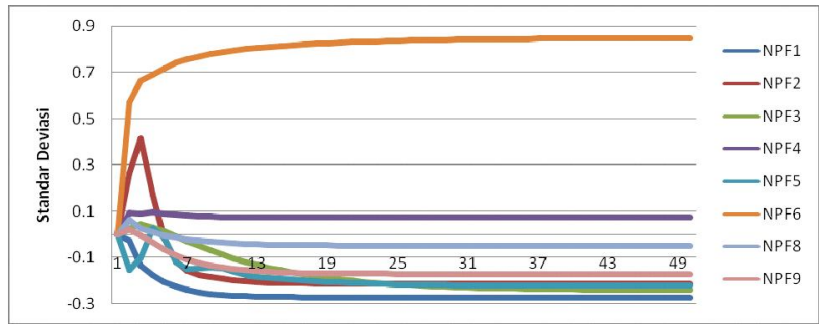

Gambar 2. Respon NPF perbankan syariah berdasarkan sektor ekonomi terhadap shock inflasi (IHK)

Berbeda halnya dengan sektor konstruksi (NPF4) dan sektor pengangkutan, pergudangan dan komunikasi (NPF6) yang merespon positif terhadap guncangan inflasi. N PF sektor sektor pengangkutan, pergudangan dan komunikasi (NPF6) merespon positif lebih besar dibandingkan sektor konstruksi (NPF4). Hal ini dapat diakibatkan karena tingginya inflasi dan umumnya permintaan pada sektor ini bersifat elastis. Berdasarkan data Badan Pusat Statistik, inflasi pada sektor pengangkutan, pergudangan dan komunikasi tahun 2013 dan 2014 merupakan terbesar dibandingkan sektor lainnya yaitu sebesar 15,36 dan 12,14 persen. Permintaan pada sektor pengangkutan, pergudangan dan komunikasi pada umumnya bersifat elastis sehingga kenaikkan harga akan berimplikasi pada penurunan permintaan. Oleh karenaitu, guncangan inflasi dapat menyebabkan penurunan pendapatan sehingga mengakibatkan penurunan repayment capacity pada sektor pengangkutan, pergudangan dan komunikasi kepada bank syariah.

\section{Pengaruh Guncangan Nilai Tukar terhadap NPF}

Berdasarkan Gambar 3, respon positif ditunjukkan terhadap guncangan nilai tukar oleh N PF sektor pertanian, kehutanan dan sarana pertanian (NPF1), pertambangan (NPF2), perdagangan, restoran dan hotel (NPF5), jasa dunia usaha (NPF8), dan jasa sosial/ masyarakat (NPF9). NPF sektor jasa sosial/ masyarakat (NPF9) merespon positif lebih besar dibandingkan sektor lainnya. Menurut Yudanto dan Santoso (1998) sektor jasa sosial/ masyarakat yang terdiri dari sub sektor pemerintah dan rumah tangga sangat tergantung pada anggaran sehingga penyesuaian anggaran dengan gejolak nilai tukar dalam arti rupiah terdepresiasi pada akhirnya mempengaruhi penurunan produksi. Penurunan produksi berimplikasi pada re payment capacity kepada bank syariah yang tercermin pada peningkatan rasio N PF sektor jasa sosial/ masyarakat.

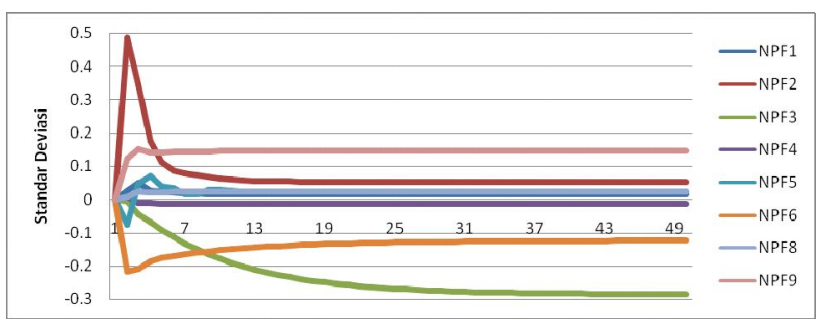

Gambar 3. Respon NPF perbankan syariah berdasarkan sektor ekonomi terhadap shock nilai tukar

Respon negatif ditunjukkan terhadap guncangan nilai tukar oleh NPF sektor perindustrian 
(NPF3), konstruksi (NPF4), dan pengangkutan, pergudangan dan komunikasi (NPF6). NPF jasa sektor perindustrian (NPF3) merespon negatif lebih besar dibandingkan sektor lainnya. $\mathrm{Hal}$ ini dapat diakibatkan dengan melihat sisi ekspor sektor industri dimana nilai tukar akan sangat berpengaruh pada pendapatan sektor ini. Berdasarkan data dari Kementrian Perindustrian, ekspor sektor industri pada tahun 2014 meru pakan sektor dengan kontribusi terbesar dibandingkan sektor lainnya dengan kontribusi sebesar 66,55 persen. Gejolak nilai tukar dalam arti rupiah terdepresiasi akan mengakibatkan peningkatan pendapatan dari sisi ekspor pada sektor ini dan berimplikasi pada peningkatan repayment capacity kepada bank syariah yang tercermin pada penurunan rasio NPF sektor industri. H ubungan negatif yang ditunjukkan antara guncangan nilai tukar terhadap NPF sesuai dengan hasil penelitian Poetry \&Sanrego (2012).

\section{Pengaruh Guncangan IPI Terhadap NPF}

Berdasarkan Gambar 4, respon positif ditunjukkan terhadap guncangan IPI oleh NPF pertambangan (NPF2), perindustrian (NPF3), konstruksi (NPF4), perdagangan, restoran dan hotel (NPF5), dan pengangkutan, pergudangan dan komunikasi (NPF6). Peningkatan pertumbuhan ekonomi akan menyebabkan ekspektasi pembiayaan perbankan untuk lebih berekspansi. $N$ amun menurutDjaman (2005) bahwa ekspansi pembiayaan besar-besaran oleh perbankan yang jika tidak dilakukan dengan pengawasan ketat akan meningkatkan rasio NPF.

NPF sektor pertambangan (NPF2) merespon positif lebih besar dibandingkan sektor lainnya. Berdasarkan data Badan Pusat Statistik laju pertumbuhan produk domestik bruto sektor pertambangan tahun 2012, 2013 dan 2014 cenderung mengalami penurunan yang masing-masing sebesar sebesar 2,19; 0,43; dan -0,69 persen. Hal ini mengindikasikan peningkatan pertumbuhan ekonomi nasional tidak menjamin seluruh sektor eko- nomi meningkat seperti terjadi pada sektor pertambangan sehingga akan berpengaruh terhadap penurunan repayment capacity kepada bank syariah yang tercermin pada peningkatan rasio N PF sektor pertambangan. Hubungan positif yang ditunjukkan antara guncangan IPI terhadap NPF sesuai dengan hasil penelitian Poetry \&Sanrego (2012).

Respon negatif ditunjukkan terhadap guncangan IPI oleh NPF sektor pertanian, kehutanan dan sarana pertanian (NPF1), jasa dunia usaha (NPF8), dan jasa sosial/ masyarakat (NPF9).NPF sektor jasa sosial/ masyarakat (NPF9) yang merespon negatif lebih besar dibandingkan sektor lainnya. Berdasarkan data Badan Pusat Statistik laju pertumbuhan produk domestik bruto sektor jasajasa tahun 2012, 2013 dan 2014 cenderung mengalami peningkatan yang masing-masing sebesar sebesar 5,37; 5,75; dan 5,83 persen. Hal ini mengindikasikan peningkatan sektor jasa sosial/ masyarakat sejalan dengan peningkatan pertumbuhan ekonomi nasional sehingga akan berpengaruh terhadap peningkatan repayment capacity kepada bank syariah yang tercermin pada penurunan rasio NPF sektor jasa sosial/ masyarakat. Hubungan negatif yang ditunjukkan antara guncangan IPI terhadap NPF sesuai dengan hasil penelitian N ursechavia \& A bduh (2014).

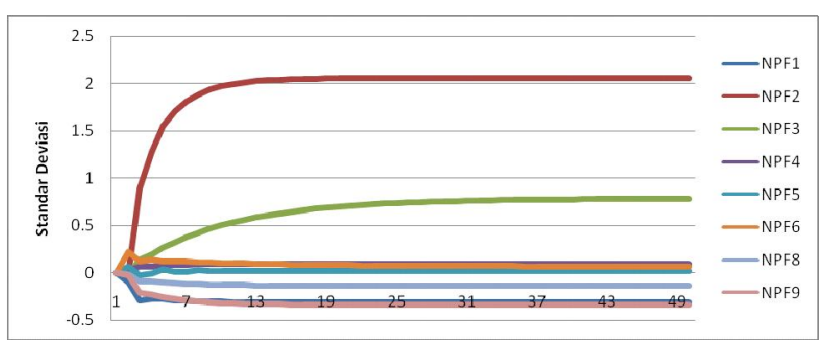

Gambar 4. Respon NPF perbankan syariah berdasarkan sektor ekonomi terhadap shock IPI

\section{Analisis Forecast Error Variance Decomposition (FEVD)}

Setelah menganalisis perilaku dinamis melalui analisis impulse response, tahapan selanjutnya 
Kaitan Kondisi Makroekonomi dengan Non Performing Financing Berdasarkan Sektor Ekonomi ...

N unung N uryartono, Imam Teguh Saptono, \& G uruh H erman Was'an

akan dilihat karakteristik model melalui forecast error variance decomposition (FEVD) dimana dalam analisa ini akan melihat seberapa besar kontribusi setiap variabel terhadap variabel pembiayaan bermasalah masing-masing sektor ekonomi.

Tabel 7 menunjukkan dalamjangka panjang, pengaruh guncangan NPF masing-masing sektor ekonomi terhadap dirinya sendiri semakin menu- run menurut waktu sementaraitu variabel makroekonomi lain memberikan kontribusi yang berbeda-beda kepada N PF masing-masing sektor ekonomi. Inovasi variabel nilai tukar cenderung merupakan inovasi terkecil dalam jangka pendek maupun jangka panjang. Hal ini sesuai dengan hasil penelitian Mutamimah dan Zaidah (2012) dan Poetry \&Sanrego (2012). N amun demikian nilai tukar

Tabel 7. Variance decomposition model NPF berdasarkan sektor ekonomi

\begin{tabular}{|c|c|c|c|c|c|c|c|c|c|c|c|}
\hline Period & NPF & SBIS & IHK & ER & IPI & Period & NPF & SBIS & IH K & ER & IPI \\
\hline \multicolumn{6}{|c|}{ Variance Decomposition of NPF1: } & \multicolumn{6}{|c|}{ Variance Decomposition of NPF5: } \\
\hline 1 & 100.00 & 0.00 & 0.00 & 0.00 & 0.00 & 1 & 100.00 & 0.00 & 0.00 & 0.00 & 0.00 \\
\hline 2 & 90.73 & 8.41 & 0.00 & 0.01 & 0.84 & 2 & 97.61 & 0.11 & 1.84 & 0.19 & 0.24 \\
\hline 12 & 70.35 & 9.64 & 5.04 & 1.58 & 13.39 & 12 & 93.96 & 2.32 & 3.27 & 0.31 & 0.15 \\
\hline 24 & 67.53 & 7.85 & 7.05 & 2.02 & 15.55 & 24 & 90.22 & 3.27 & 6.13 & 0.25 & 0.13 \\
\hline 36 & 66.56 & 7.23 & 7.75 & 2.17 & 16.30 & 36 & 88.26 & 3.66 & 7.72 & 0.23 & 0.13 \\
\hline 48 & 66.07 & 6.91 & 8.10 & 2.24 & 16.67 & 48 & 87.17 & 3.87 & 8.61 & 0.22 & 0.13 \\
\hline \multicolumn{6}{|c|}{ Variance Decomposition of NPF2: } & \multicolumn{6}{|c|}{ Variance Decomposition of NPF6: } \\
\hline 1 & 100.00 & 0.00 & 0.00 & 0.00 & 0.00 & 1 & 100.00 & 0.00 & 0.00 & 0.00 & 0.00 \\
\hline 2 & 98.64 & 0.00 & 0.24 & 1.12 & 0.00 & 2 & 90.61 & 2.13 & 5.90 & 0.39 & 0.97 \\
\hline 12 & 67.06 & 10.04 & 0.52 & 3.85 & 18.53 & 12 & 73.73 & 2.54 & 22.43 & 0.63 & 0.67 \\
\hline 24 & 58.93 & 14.20 & 0.63 & 4.07 & 22.17 & 24 & 69.88 & 2.48 & 26.62 & 0.54 & 0.49 \\
\hline 36 & 56.48 & 15.47 & 0.66 & 4.14 & 23.25 & 36 & 68.27 & 2.47 & 28.37 & 0.49 & 0.40 \\
\hline 48 & 55.31 & 16.07 & 0.68 & 4.17 & 23.76 & 48 & 67.41 & 2.47 & 29.31 & 0.46 & 0.35 \\
\hline \multicolumn{6}{|c|}{ Variance Decomposition of NPF3: } & \multicolumn{6}{|c|}{ Variance Decomposition of NPF8: } \\
\hline 1 & 100.00 & 0.00 & 0.00 & 0.00 & 0.00 & 1 & 100.00 & 0.00 & 0.00 & 0.00 & 0.00 \\
\hline 2 & 99.83 & 0.12 & 0.04 & 0.00 & 0.01 & 2 & 98.05 & 0.61 & 1.26 & 0.00 & 0.08 \\
\hline 12 & 85.45 & 3.09 & 0.75 & 0.06 & 10.66 & 12 & 92.24 & 0.38 & 0.50 & 0.28 & 6.60 \\
\hline 24 & 72.78 & 5.61 & 2.46 & 0.12 & 19.03 & 24 & 90.15 & 0.20 & 0.38 & 0.43 & 8.84 \\
\hline 36 & 67.21 & 6.67 & 3.40 & 0.15 & 22.56 & 36 & 89.36 & 0.13 & 0.35 & 0.49 & 9.67 \\
\hline 48 & 64.43 & 7.20 & 3.89 & 0.17 & 24.31 & 48 & 88.96 & 0.10 & 0.33 & 0.52 & 10.09 \\
\hline \multicolumn{6}{|c|}{ Variance Decomposition of NPF4: } & \multicolumn{6}{|c|}{ Variance Decomposition of NPF9: } \\
\hline 1 & 100.00 & 0.00 & 0.00 & 0.00 & 0.00 & 1 & 100.00 & 0.00 & 0.00 & 0.00 & 0.00 \\
\hline 2 & 97.61 & 1.67 & 0.65 & 0.02 & 0.05 & 2 & 98.58 & 0.63 & 0.06 & 0.69 & 0.04 \\
\hline 12 & 94.25 & 3.43 & 1.21 & 0.03 & 1.09 & 12 & 92.50 & 0.43 & 0.34 & 0.30 & 6.42 \\
\hline 24 & 93.97 & 3.47 & 1.16 & 0.03 & 1.37 & 24 & 90.49 & 0.21 & 0.71 & 0.19 & 8.40 \\
\hline 36 & 93.87 & 3.49 & 1.14 & 0.03 & 1.47 & 36 & 89.75 & 0.14 & 0.85 & 0.14 & 9.11 \\
\hline 48 & 93.83 & 3.49 & 1.13 & 0.03 & 1.52 & 48 & 89.38 & 0.11 & 0.92 & 0.12 & 9.47 \\
\hline
\end{tabular}




\section{Jurnal Keuangan dan Perbankan | PERBANKAN}

Vol. 20, N o.1, Januari 2016: 104-115

tetap memiliki pengaruh terhadap kinerja perbankan syariah seperti yang diungkapkan Soelaksono (2013) hal tersebut dikarenakan komposisi pembiayaan perbankan syariah lebih didominasi oleh skema murabahah sehingga kestabilan nilai tukar tetap diperlukan terutama bagi pengusaha ekspor impor.Komposisi pembiayaan dengan akad murabahah hingga Desember 2014 pada perbankan syariah sebesar 58,88 persen berimplikasi juga pada kecilnya pengaruh perubahan imbal hasil acuan terhadap NPF.

Dalam interval peramalan pada periodepertama varians NPF seluruh sektor ekonomi sangat dipengaruhi oleh NPF sektor ekonomi itu sendiri sebesar 100 persen.Variabilitas inovasi variabel makroekonomi mulai dirasakan pada periode kedua karena pengaruh perubahan kondisi makroekonomi memerlukan waktu untuk mempengaruhi aspek lainnya. Variabilitas inovasi variabel pada periode kedua paling dirasakan yaitu pada NPF sektor pertanian, kehutanan dan sarana pertanian (NPF1) dan sektor pengangkutan, pergudangan dan komunikasi (NPF6) dengan masing-masing kontribusi variabel imbal hasil SBIS sebesar 8,41 dan 2,13 persen, inflasi sebesar 0,00 dan 5,90 persen, nilai tukar sebesar 0,01 dan 0,39 persen, dan pertumbuhan output (IPI) sebesar 0,84 dan 0,97 persen. Dalam jangka panjang terlihat variabilitas inovasi variabel paling dirasakan pada periode ke 48 yaitu pada NPF sektor pertambangan (NPF2) dan sektor perindustrian (NPF3) dengan masingmasing kontribusi variabel imbal hasil SBISsebesar 16,07 dan 7,20 persen, inflasi sebesar 0,68 dan 3,89 persen, nilai tukar sebesar 4,17 dan 0,17.

\section{KESIM PULAN}

Berdasarkan hasil pengujian impulseresponse, respon positif terbesar terhadap guncangan imbal hasil SBIS ditunjukkan NPF sektor pertambangan. Sedangkan respon negatif terbesar terhadap guncangan imbal hasil SBIS ditunjukkan oleh NPF pengangkutan, pergudangan dan komunikasi.
Sedangkan guncangan inflasi direspon negatif oleh hampir seluruh NPF sektor ekonomi kecuali NPF sektor konstruksi dan sektor pengangkutan, pergudangan dan komunikasi. Guncangan nilai tukar direspon positif lebih besar dibandikan sektor lainnya oleh N PF sektor jasa sosial/ masyarakat dan direspon negatif lebih besar ditunjukkan oleh NPF sektor perindustrian.Respon positif terbesar ditunjukkan terhadap guncangan IPI oleh NPF pertambangan sedangkan respon negatif terbesar ditunjukkan oleh NPF sektor jasa sosial/ masyarakat. Sesuai dengan dugaan awal bahwa respon yang ditimbulkan masing-masing NPF sektor ekonomi akan berbeda terhadap perubahan kondisi makroekonomi.

Berdasarkan hasil pengujian variance decomposition Inovasi variabel nilai tukar cenderung merupakan inovasi terkecil dalam jangka pendek maupun jangka panjang. Dalam jangka pendek ataupun dalamjangka panjang, perubahan variabel makroekonomi sangat berpengaruh terhadap N PF dari empat sektor dengan besaran variabilitas tiga puluh hingga lima puluh persen yaitu NPF sektor pertanian, kehutanan dan sarana pertanian, sektor pertambangan, sektor perindustrian, dan sektor pengangkutan, pergudangan dan komunikasi .

\section{SARAN}

Berdasarkan hasil analisis, beberapa implikasi yang dapat dirumuskan adal ah penerapan early warning system terhadap perubahan kondisi makroekonomi khususnya inflasi dan pertumbuhan ekonomi/ ouput terutama terhadap empat sektor yaitu sektor pertanian, kehutanan dan sarana pertanian, sektor pertambangan, sektor perindustrian, dan sektor pengangkutan, pergudangan dan komunikasi; pengembangan produk dan kebijakan pembiayaan dengan penyesuaian karakteristik masing-masing sektor ekonomi yang akan dibiayai tanpa melanggar prinsip syariah; menjaring dan meningkatkan sumber daya manusia (SDM) yang memiliki komitmen syariah dan kompetensi sesuai 


\section{Kaitan Kondisi Makroekonomi dengan Non Performing Financing Berdasarkan Sektor Ekonomi ...}

N unung N uryartono, Imam Teguh Saptono, \& G uruh H erman Was'an

dengan masing-masing sektor ekonomi yang akan dibiayai; penyesuaian penyaluran pembiayaan kepada sektor ekonomi yang sesuai dengan karakter ataukompetensi perbankan syariah itu sendiri; melakukan maintenance kepada nasabah pembiayaan secara berkesinambungan terutama pembiayaan yang sudah masuk kriteria dalam perhatian khusus atau kolektibiltas dua agar tidak masuk ke kriteria NPF; dan untuk nasabah NPF sendiri, perbankan syariah dapat membuat kebijakan sesuai dengan kemampuan bayar nasabah seperti pemberian keringanan bagi debitur seperti restructuring, reconditioning, atau rescheduling.

Penelitian ini hanya menggunakan variabel makroekonomi sebagai salah satu indikator yang mempengaruhi NPF.Oleh karena itu untuk mendapatkan hasil yang lebih baik diharapkan penelitian selanjutnya mempertimbangkan menggunakan variabel-variabel kuantitaf seperti variabel mikro dan kualitatif baik dari segi perilaku perbankan atau pelaku usahanasabah perbankan syariah.

\section{DAFTAR PUSTAKA}

Bank Indonesia. 2007. Cetak Biru Pengembangan Perbankan Syariah di Indonesia. Jakarta: BI.

Djaman DS. 2005. Faktor-Faktor yang M empengaruhi O utstanding Kredit dan Rasio O utstanding N on-Lancar KUK BNI. [Tesis]. Jakarta: PSKTTI - Universitas Indonesia.
Enders W. 2004.A pplied Economic Time Series.2 ${ }^{\text {nd }}$ Edition. Alabama: Jhon Wiley

Gujarati D. 2003.Basic Econometrics.4 ${ }^{\text {th }}$ Edition. New York: McGraw-Hill.

Mutamimah, Zaidah SN. 2012. Analisis Eksternal dan Internal dalam Menentukan Non Performing Financing Bank Umum Syariah di Indonesia. Jurnal Bisnis dan Ekonomi (JBE). 19 (1): 49-64.

N ursechafia, A bduh M. 2014. The Susceptibility of IsIamicBank's CreditRisk Towards Macroeconomic Variables. Journal of Islamic Finance. 3(1): 023-037.

Peraturan Bank Indonesia N omor: 13/ 23/ PBI/ 2011 Tentang Penerapan M anajemen Risiko Bagi Bank U mum Syariah dan U nit U saha Syariah.

Poetry ZD, Sanrego YD. 2011.Pengaruh Variabel Makro dan Mikro Terhadap NPL Perbankan Konvensional dan N PF Perbankan Syariah.Journal oflslamic Finance \& Business Review.6 (2).

Soelaksono A. 2013. Prilaku Dinamis Kredit Perbankan Konvensional dan Syariah Serta Kaitannya Dengan Kondisi M akroekonomi di Indonesia.[Tesis]. Bogor: Sekolah Pascasarjana Institut Pertanian Bogor.

Yudanto N, Santoso MS. 1998. Dampak Krisis Moneter Terhadap Sektor Riil [catatan penelitian]. UREM$\mathrm{BI}: 1$ (2). 